\title{
Stimulating Women Potentials through Entrepreneurship for National Development in Nigeria.
}

\author{
${ }^{1}$ Amuchie Austine A., ${ }^{2}$ Asotibe Ngozi P, ${ }^{3}$ Ikpa Ebere G \\ College Of Education Zing, Taraba State \\ ${ }^{1} \& 3$ Department Of Business Education, College Of Education Zing, Taraba State, Nigeria. \\ Collegeofmid Wiffrey Jalingo, Taraba State, Nigeria. North East Nigeria
}

\begin{abstract}
Women over the years have been faced with the problem of marginalization in virtually all human endeavors This male chauvinism and gender inequality in our society in the name of culture have done more harm than good to the economy d socio-political development of the country as women entrepreneurshipis greatly "hampered in this respect most especially in the formal sector This paper therefore examined the level of women participation entrepreneurship which include among others, finance, limited mobility, family ties, education and risk bearing abilities The paper is of the opinion that development cannot be fully realized Nigeria if women who constitute almost half of the population are not being carried along and suggested that women should be treated as specific target group in all development programs and that government should create enabling environment that will promote entrepreneurship development among women by discouraging all forms of discrimination against them fortheirpotentials tobefully harnessed for national development.
\end{abstract}

\section{Introduction}

Yesufu (2000), observe that hardly is there any aspect of Nigeria national life in recent times that has received so much attention as the role of women in the development of the economy. There is virtually no any area of human lives that women have found it easy. Women around the globe are being discriminated against in employment, in hiring, job security and power dispensation

Statistically, Nigeria women constitute about half of the country's population (Ojo, 1997 and Yesufu, 2000) they are indeed better half of the society.However, in real life, oursociety is still male- determined Women are not accorded equal treatment as their malecounterparts both within and outside the four walls of the homes.Infact, they are treateddisdainfully and considered not competent and as such dependent on men (Khaka,2000).

In our traditional society, men havealways played dominant role by underrating women. In many Nigeria homes, women are neglected to the background (Oguche and Rabah,2001).

Also, there isan apparent high level of discrimination against females with regard to recruitment into employment as noticed by Yesufu (2000). He said that females numbering 44,462,621 constitute $46.96 \%$ of the total population of Nigeria in 1991 census. He stressed further that the potential labour force in Nigeria consisting of people in age group 15-64 years inclusive was 46,091,452 of which female numbered 23,675,975 which is approximately 51.4 percent. He observed, that in spite of this, males are far more than the females in respect of total employed labour force, The male formed 62.6 percent while the females are just 37.4 percent which was further confirmed their advantage position in the society.

In the education sector there is also a wide gender gap The situation according toOguche and Rabah (2001) is generally worse in northern part of the country where at least.85.7\% of the females are illiterate as against $31.1 \%$ of the females are educated in the Southernpart of the country. Another fact that further exacerbate the condition of women in Nigeria is the age-long socio-cultural tradition and taboos confining the women within the four walls oftheir homes. Therefore, the combination of this factors serve as unfavorable conditions for the emergence and development of women entrepreneurship in Nigeria especially in the formal sector of the economy. It is therefore against this background of disadvantaged position of women that the paper looks at how the women potentials can be harnessed throughentrepreneurship formational development.

In order to achieve the above objective, the rest of this paper has been structured as follows: Part one gives the meaning of some concepts; part two addresses the level of women participation in entrepreneurial activities in the informal and formal sectors: part three discusses the problem of women entrepreneurs in Nigeria: part four identifies some government's efforts in promoting women entrepreneurship in Nigeria; while part five suggests ways womenentrepreneurship could be harnessed for national development. Lastly is the summary and concluding part. 


\section{Entrepreneurship}

\section{Conceptual Clarification}

This concept has been debated and discussed by scholars educators, researchers and policy makers overthe years. Being an exclusive concept, it has being defined differently by several people. According to Khanka (2000), entrepreneurship is an attempt to create value through recognition of business opportunity, the management of risk-taking appropriate to the and through communicative and management skills to mobilize human, financial and material recourses necessary to bring a project into fruition.

Nwokolo (1997) sees entrepreneurship as involving the ability to set up a business enterprises as different from being employed by somebody else. He stressed that it involves the acquisition of skills idea and managerial abilities that are necessary for personal self-reliance. While Lawal and Oguche (2004) refers to entrepreneurship as the act or process of identifying business opportunities and organizing them initiate a successful business activity and profit. It isthe ability-to perceive profitable business opportunities and willingness toacton what isperceivedand the necessary organizing skills associated whit the project.

Schumpeter in Zakari (2006) tied entrepreneurship to the creation of a new product,introduction of anew method of production, opening of a new market, the conquest of anewsource of supply and carrying out of a new organization of industry.

Salhman in Ojukwu(1999) defines entrepreneurship as the relentless pursuit ofopportunity withoutregard to resources currently controlled. One of the best definitions ofentrepreneurship was developed by Timmons (1994) in Lambing and Kuchi (1997) as

'A human creative act that bids something of value from practical nothing.it is of pursuit of opportunity regardless of the resources or lack of resources at hand. It requires a vision and the passion and commitment to lead others in the pursuit of that vision. It also require a willingness to take calculate risk'

From the above plethora of definitions, entrepreneurship can be seen as the functions performed by an entrepreneur in setting up an enterprise. It is the process that entails the various activities require in order to set up an enterprise.

\section{Entrepreneur}

Nwokolo (1997) defines entrepreneur as a person who makes profit by starting or running a business of his own especially when it involves taking financial risks.

Entrepreneur, according to Drucker in Lambing and Kuchi (1997) is defined as one who shifts economic resources out of an area of lower and in to a area of higher-productivity and greater yield.

Knight in Khanka (2002) defines entrepreneur as the economic functionary who undertake such responsibility of uncertainty which by its very nature can not be insured, nor capitalizednor salaried too. It is on this note that Khanka (2002) defines women entrepreneurs as awoman or group of women who initially organize and run a business enterprise. Womenenterprises can also be seen as those women who think of a business enterprise, initiate it organized and combined the factors of production. Operate the enterprise and undertake the risks and handle economic uncertainty characterized running a business enterprise' $A$ human creative act that bids something of value from practical nothing. It is of pursuit of opportunity regardless of the recourses or lack of resources at hand. It requires a vision and the passion and commitment to lead others in the pursuit of that vision. It also require a willingness to take calculate risk'

From the above plethora of definitions, entrepreneurship can be seen as the functions performed by an entrepreneur in setting up an enterprise. It is the process that entails -the various activities require in order setting up an enterprise.Level of women participation in entrepreneurial activities in the formal sector Business enterprise could be classified in to formal or informal/organized sector. It issaid to be informal when they are not registered are mostly owned and managed by oneperson who may be assisted occasional by members ofhis. There family and without fixed:address but with small capital employed to the running of the business (Lawal 2000). The International Labour Organization (1972) in Ojo (1997) gave the followingcharacteristic of the informal sectors as follows ease of entry reliance on local resourcesfamily ownership of enterprises small scale of operations labour intensive and adoptedtechnology skills acquisition outside the formal system of education and training andunregulated and competitive marketYesufu (2000) observed that the informal sector has been the area where womenentrepreneurs are more actually involved In the recent times, this sector has witnessed atremendous growth Its employment for women, according to Ojo (1997), covers activitiessuch as agriculture, trading, domestic activity, hairdressing as well as crafts and cottage inindustries such as weaving, soap making and pottery Informal sector trading seems to bethe most popular occupation of women in Nigeria most especially in the western stateAkanji (1996) sees the major operators of this sector to be women who have thecultural and social barriers of playing the second fiddle, but still have to make ends meetcater for their children and extended family However, the informal sector has beenneglected despite its significant contributions to the economy. The following, accordingAliyu (1998) were deduced tobe the possible reason 
The large and fragmented nature of the sector characterized by numerous economy units with activities spread over equally numerous sectors.

- Very little available information in the sector to assist in the formulation of relevant policies, and

- Lower level of education, training and technological know- how of operation in this sector.

\section{Level of Women Participation in Entrepreneurial Activities in the Organized $\backslash$ Formal Private Sector}

This sector has received strong backing from the successive Nigerian governments and the United Nations Agencies (Ahyu 1998) The sector has the following main features difficult entry regulated market and possession of formal education

Successive governments have provided increasing number of enlightenments and incentives to this sector with special provisions to the small and medium enterprises. This is as a result of global realization of the overwhelming importance of this sector.

Despite the incentives provided by government to this sector such as tax holidays and favorable policy reforms, women have not availed themselves of these opportunities offered to invest in this sector. It is more dominated by their male counterparts (Yesufu,2000). The reason for the less involvement of women in this sector according toOjo (1977), is due to their contracting features.

\section{Problems of Women Entrepreneurs in Nigeria}

Women entrepreneurs are faced with two kinds of problems. These are: the general problems of entrepreneur and problems specific to women entrepreneurs.

\section{i. Inadequatecapital}

The role of finance cannot be overemphasized. Many women enterprises fail because of shortage of capital, which is often regarded as, the life-wire of any business enterprise either small orbig. According to Lambing and Kuchi (1997), it is believed that women do not have equal access to capital when the need it due to hick of collateral necessary to obtain bank loans. The have no property on their names to use as collateral for obtaining funds from external source of funds. This is supported by Akanji (1996) who says that unless women have spent years haggling with bureaucrats, the have no title to their property and cannot get mortgages or insurance In some cases too, women are considered by lending institutions to be less credit-worthy as they can leave their informal financial sources. They are bound rely in their personal savingsor any esusu, and loan from friends and relatives, which may be negligible. Thus, this shortage of funds limits the rate of growth of their business.

\section{ii. Low level of education}

This is the most important barrier to female participation in entrepreneurial activities in the formal sector. As we have noticed that at least $85.7 \%$ of females in the Northern part are uneducated (Oguche and Rabab, 2001). Illiteracy as been seen by Khanka (2000) as the root cause of socio-economic problems. Women are usually not aware of business technology and market knowledge due to lack of education. Lack of education has been discovered to bring about low motive for achievement, which is one of the driving force that peoples a potential entrepreneur. This problem therefore hinders women in establishing and running business enterprise.

\section{iii. Family ties}

The Nigerian society, one of the basic duties of womenis to look after the children and other members of the family. The male on the otherhand plays security role. A married woman has a divided mind. She has to strike a balance (or compromise) between her business and family. This leaves little or no energy and time to devote to business. The support and approval of the husband is a necessary condition for women entering into business.

\section{iv. Competition.}

Women entrepreneurs are faced with competition both in the marketing of their productswith both formal sector on one hand and due to their inability to pump in a lot of money for advertising.

\section{v. Male dominated society}

Our society promotes a rigid chauvinistic role to keep women in their place (Molemodile.2000) male chauvinism is still the order of the day. Despite the fact that the country in1984, signed UN Declaration on the elimination of all forms of discrimination againstwomen, and the Millennium Development Goals of promotion of gender equality andwomen empowerment, women are still looked upon as weak in all respects. They sufferfrom male reservation about a woman's role, ability and capacity and are treated accordingly. 


\section{vi. Limited mobility}

Although we now have women who trade across the borders, the society still looksupon a single woman asking for a room with suspicion. At the end of the day many of ourwomen give up the ideaof starting an enterprise of their own (Akanji 1996).

\section{vii. Low need for achievement.}

Women according to Lambing \&Kuehi (1997) define success as having control over their own destinies, building on-going relationships with clients, and doing something fulfilling while men define success in terms of achieving goals. They stress that women success is partially defined by home and family life. For this, women entrepreneur have low desire to achieve high goals in business. Some prefer to remain small by choices.

\section{viii. Low risk bearing ability}

Risk bearing is an essential requisite of a successful entrepreneur. Due to the lowliteracy level and economic dependency of Nigeria women, their ability to accommodaterisk involved in running an enterprise is reduced.

\section{Government Efforts in promoting Women Entrepreneurship in Nigeria}

Nigeria government has put in place institutional arrangements for the articulation and implementation of programs and projects that are women oriented in order to foster the role of women in development (Oguche and Lawal, 2004). These include:

i. The establishment of national commission for women by decree 30 of 1989 , which became operational in 1990. It is aimed at developing policies and programs that could enhance the status of Nigeria women and address the various issues militating against their full participation in the development process. It has as one of its objectives to encourage the sense and essence of cooperative society and activities among women both in urban and rural areas and stimulate in them, creative entrepreneurship in the field of cottage industries and small scale industries.

ii. Better life programme was initiated in 1987 to improve the status of Nigeria women. It corroborated with the government, private and non-governmental organizations (e.g. National Council of Women Societies) to provide vocational training and credit facilities for women. It also promoted their cottage industries and the marketing of their products. Better life programme was absorbed into theNational commission for women which later metamorphosized in to family support programme before its demise.

iii. National Directorate of Employment (NDE) was set up to combatthe several problem of employment through vocational training and unemployment generations. The women's employment branch of the NDE lays emphasis on women employment issue.

iv. Women education sections have been set-up in federal and state ministries to spearhead and collate activities to assist women achieve access to education. Several girls secondary schools have been establish in all levels of government (Federal, State; Local Governments).

v. National council on education (NCE) in 1986 endorsed policy objective for female education. Parts of the policies for female education are: creating awareness in citizens on thefact that equal education opportunities exist irrespective of gender, age, locality, creed or status and should therefore be available. Other responsibility include the provision of basic literacy and skill acquisition for illiterate females and early school leavers through skill such as sewing, cooking, baking, typing, knitting and subsistence and the awakening of the consciousness of women to the need for the development of positive self image.

Also, there are several non- governmental organizations that have helped in promoting women entrepreneurship in Nigeria e.g. Nigerian Women Entrepreneurs.

However, despite all efforts in stimulating entrepreneurial competencies in women through the aforementioned institutions, Aliyu (2003), observed that such effort have failed due to some reason such as poor policy frameworks, institutional framework and delivery mechanism, absence of target setting for ministries, agencies and programmes, absence of coordination, implementation and monitoring, absence of effective collaboration and complementation among the three ties of governments, duplication of function among institution and agencies, unhealthyrivalries among institution and agencies, lack of involvement of the traditional authorities and community group in projects selection and implementation etc.

\section{The Role of Women Entrepreneurs in Economic Development}

Yesufu (2000) commented that to take Nigerian development without the participation of the women would constitute a fundamental contradiction. The more womenare gainfullyemployed, the lighter will be the 
existing dependent burden, and the greater will be the tendency and, momentum to nationaleconomic development.

Therefore, the following are some of the contributions women entrepreneurship canplay in the development of theeconomy.

- It will help to increase productivityas more goods and services will be produced andalso consumed (Yusufu, 2000).

- It will promote capital formation as funds that idle are will be mobilized for development,

- It will also encourage effective utilization of capital and skill which mightotherwise remain unutilized and idle (Khanka, 2002).

- It will also stimulate the equitable distribution ofwealth, income and even politicalpower in the interest of the country.

- it will promote balanced regional development.

- It will help to promote export trade which,according toAliyu (1 997)is an importantingredient to economic development.

- It will help to reduce the level ofin thepoverty country as many women who were notworking before are engaged in productive work.

\section{Recommendations}

* Government should treat women as specifictarget group in all developmentprogrammes.

* Government should also through its institution andagencies, promote appropriatetechnology to improve efficiency and productivity.

* Government should also assist the womenentrepreneurs creating avenue formarketing their products.

* Government as a matter of policy should make it mandatory for the commercial banks to grant to the women entrepreneurs who have viable projects $\mathrm{n}$ order to complement the effort of Nigeria Agricultural and Cooperative Bank, the Family Economic Advancement Program and Small and Medium Industries Equity InvestmentScheme (SMEIS).

* Government should also introduce product and process-oriented courses through NDEto enable women start small scale industries.

* Government should also try to in calculate the entrepreneurial education in schools, colleges and polytechnic to spur our graduates to opt for self employment.

* Women literacy level should be improved through UBEprogrammes

* There should be enlightenment, campaigns by the government through National Orientation Agency to eliminate all forms of discriminations against women based on religion, tradition and customs.

* Government should create a congenial environment for developing women entrepreneurship in rural and urban areas.

\section{Conclusion}

Women entrepreneur have increased rapidly over the years most especially in the late 1980 and 1990s. There are many reasons that could be accounted for that. These include lay-offs from government work as a result of introduction of SAP, lack of meaningful work opportunities and job security coupled with the desire for flexibility in working hours.

Women entrepreneurs are faced with two type of problems general problems faced by all entrepreneurs irrespective of their gender as well as problems that are peculiar to women Nigeria women, entrepreneur are generally found in the informal sector due to some problems considered peculiar to women entrepreneurs which include family ties, education, risk-bearing abilities, finance and their lack of need for achievement coupled with their choice to make, their enterprises small.

For government to be able fully harness women potentials for national development, women have to be integrated in to the nation'sdevelopment program. Effort must be made to totally discourage all forms of discriminations against women as it could be counter-productive and may serve as a clog in the wheel of development of Nigeria.

Finally, for Nigeria to witness any meaningful development, women, which constitute nearly half of the total population, should be carried, along by in solving them in the decision making process.

\section{References}

[1]. Akanji, O.O. (1996). The role and level of women's participation in the informal sector: The need for data collection and monitoring, C.B.N Bullion:vol. 20(4) pp7-15.

[2]. Aliyu.A. (1998).Nigeriaeconomybreakthrough the Abacha strategies. Abuja: FEAP.

[3]. Khanka, S.S, (2000)Entrepreneurial development, New Delhi: Ravindra printers (pvt) Limited

[4]. Lambing, P \&Kuehi, C. (1997).Entrepreneurship. New Jersy: Prentice-Hall. Inc 
[5]. Lawal, K. O\&Oguche A.A. (2004).Harnessing women potentials through womenentrepreneurship for National development. Being a Paper presented at the National Conference organized by the Association for the promotion of studies in Art and Social sciences (NAPA SASS ) atAdekunleAjasin University, AkungbaAkoko. Ondo State Nigeria, from 22-26th November; 2004.

[6]. Molemodile, V.S. (2000). The female minority problem in Nigeria: the question ofjusticeor oppression. VS. Molemodile(eds.). Nigerians, Enugu: Vougasen limited

[7]. Nwokolo, P.O. (1997), Entrepreneurship in Technology Education in Umunze(ecL). Entrepreneurship Practices in Education (Technical) pp 17-21

[8]. Ogunche, D. \&Rabah, M.H. (2001). The universal basic education: planning, implementation and sentence Onitsha Africana FEP publishers limited

[9]. Ojo, F. (1997). Human recourses management: theory and practices. Lagos: Panaf publishing Inc.

[10]. Ojukwu, K. (1999). Entrepreneurship education for self-employment. Journal of management and technology Vol. (i)pp7J-76

[11]. Yesufu, T.M. (2000). The human factor in national development.Ibadan: SpectrumBooks Limited.

[12]. Zakari, LM. (2006). Entrepreneurship: prospects and challenges. ICAN students Jaurnai.Vol. 10 (i)pp 20-32. 